\title{
V T R ヘッド用材料の問題
}

\author{
東北大学金属材料研究所斎 藤 英 夫
}

\section{ヘッド用材料の問題点}

\section{1. 構成上の問題}

現在実用されているVTR 録画用のヘッドはいかなる 型式のものにせよフェライトを主体とし，テープとの接 触部分にチップとして金属材料を用いている1)ことには

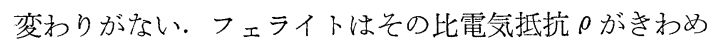
て大きく，乙たがってらず電流損失 $W_{e}$ もきわめて小さ いので, ヘッド用材料として好適なことはいうまでもな い. またその品質, 性能に関しては現在では使用者の側 汭とんぞ問題がない。唯一つの, 最大の問題は精密 な仕上げが不可能なことである。このゆえにへッドとし ての空吵損失，間隔損失を減少させるためには金属製チ ップを付ける必要がある.チップは本体に糊付けされる が，ここに一つ問題がある.すなわち貼合わせのため総 合的損失の增加が避けられない。この欠陥を除くにはチ ップを用いないこと，すなわちフェライトだけでヘッド を造るか，あるいは金属材料で全部を置き換えるかであ る.フェライトだけにするのは加工上不可能だから，こ こに金属材料としての大きな課題がある.

\section{2. チップに関する問題}

チップ自体には実にたくさんの問題が考学られるが,

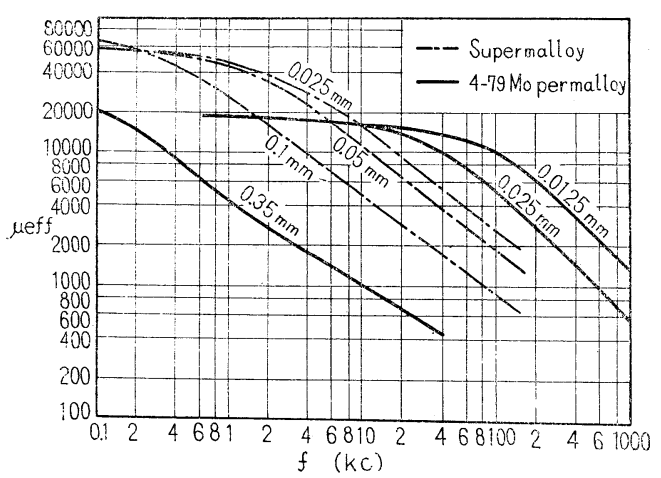

第 1 図 Superalloy $と$ Mo-permalloy $の \mu_{\mathrm{eff}}$ 周波数特性

\footnotetext{
“'Requirements Imposed on Magnetic Materials for VTR Heads' by Hideo Saito.
}

その二，三をとりまげてみよう.

第一にチップ用材料の実効透磁率 $\mu_{\mathrm{eff}}$ があまり小さ くては意味がない.しかし材料の静的特性やのだけでは 高周波特性が推測されないからその選択は実にむずかし い. 例觉ば磁性材料中最高の静的透磁率 $\mu$ を有する Supermalloy と通常の Mo-permalloy とを採り，その

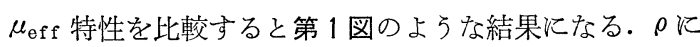
ついていえば Supermalloy で $65 \mu \Omega$-cm, Mo-perma11oy で $55 \mu \Omega-\mathrm{cm}$ であるから，磁性材料の高周波特性 は $\rho$ や静的 $\mu$ のみを以てしては予測できないことがわ かる. しかも $\mu_{\mathrm{eff}}$ は材料の磁気的構造や測定条件でも 異なるから，岕る目的にその材料が適するかぞうかは実 際の使用状態で試験しなければわからないといえよう。

第 2 に板厚である.第 1 図に見るよ5に同じ材料なら 薄いほど $\mu_{\text {eff }}$ が大さい.しかしへッドとしては磁束密 度も大きいことが必要だから有効面積もある限度以上の 大きさにせねばならぬ. 結局同じトラック幅なら薄い板 を許容し得る限り多数積層して使用した方が効果があ る. しかし加工上到達し得る厚さにも限度があるし, 次 の加工の問題もあわせて考帛ねばならないことである。

第 3 に加工の問題がある. チップは極度に精密性を要 求されるから，材料として必要な熱処理をどの段階で行 ならかが重要な課題である・一般になず打抜いて成形さ れるが，1枚だけ使用する場合はその後に必要な熱処理 を施せばすむ.しかし 2 枚以上貼合わせる場合には，第 一に貼合わせの際の加圧によってひずみが残留する恐れ がある．第二に一枚の場合も同様であるが，特に貼合わ せのものでは最後に精密仕上げを要し，これによっても ひずみが残留し得る. Lufcy ら(2)も指摘しているように

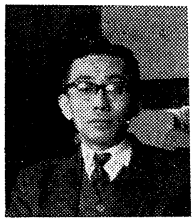

筆 者 紹 介

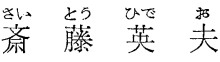
昭和 13 年北海道大学理学部物理学科卒, 直ちに東北大学金属材料研究所以入り磁性材 料, 不変鋼および恒弹性材料の研究に従事, 東北大学教授. 金属材料研究所磁性合金部担 当, 財団法人電気磁気材料研究所理事. 理博 
第 1 表 Alfenol と Permalloy の特性比較

\begin{tabular}{|c|c|c|c|c|c|c|c|c|}
\hline & $\begin{array}{l}\text { 最 } 大 \\
\text { 透磁率 } \\
\mu_{\max }\end{array}$ & 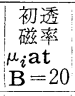 & $\begin{array}{c}\text { 保磁率 } \\
\mathrm{He}\end{array}$ & $\begin{array}{l}\text { 飧和 } \\
\mathrm{Bm}\end{array}$ & $\begin{array}{c}\text { 残留 } \\
\text { 磁気 } \\
\mathrm{Br}\end{array}$ & 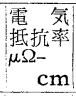 & \begin{tabular}{|l} 
硬 \\
$\square ッ ク ~$ \\
ウエル
\end{tabular} & $\frac{\text { 度 }}{\text { ブリ }}$ \\
\hline $\begin{array}{l}\text { Alfenol }(16 \% \\
\text { A1, } 84 \% \mathrm{Fe})\end{array}$ & 116,000 & 3,450 & 0.025 & 7,825 & 3,800 & 150 & $25 \mathrm{Rc}$ & 256 \\
\hline $\begin{array}{l}\text { Moly-Perm- } \\
\text { alloy }(4-79)\end{array}$ & 112,600 & 16,600 & 0.023 & 8,490 & 5,200 & 45 & $60 \mathrm{Rb}$ & 100 \\
\hline
\end{tabular}

間隔部の残留ひずみがヘッドの特性を劣下させる原因と なり得るからこれらのひずみはできるだけ避けねばなら ぬ. 特に薄い板ではひずんだ部分と板全体の容積との比 が大きくなるから非常に厄介なことである、いずれにし てもこのひずみを小さくするには機械的硬さが大きいも のをえらぶか，完全成形後さらにひずみ除去熱処理の可 能な材料をえらぶかである.ごく薄い材料では層状貼合 わせ後加工する必要があるから，ひずみ除去処理と貼合 わせ用レジン類の溶融点との関係が非常な困難を与え る. また打抜きによるバリの有無, 切断面の平滑性など も無視できない.

第 4 に耐久性である.これには磁性の安定性と機械的 耐久性とを考えねばならない。磁気的不安定性は仮りに あるとしても，ヘッドの寿命がその時効時間に比べて短 かいからほとんど問題にならない，一方テープ速度のき わめて大きいVTR ではチップの磨耗速度が非常に大き い. そして磨耗量の測定は，ヘッドなら同じ形に造り， 同じ条件の下で行なら以外に方法がない，比較的にいえ ば機械的に硬いものが酎磨耗性も大きい. しかし同じ材 料でも加工, 熱処理, 粒度によって異なるから解決はな かなか困難である.

現在ほとんどのヘッドがチッブとして $16 \% \mathrm{~A} 1-\mathrm{Fe}$ 合 金の Alperm を使用しているのは, 以上の諸点で比較 的無難であるからである. 以下少しくこの合金について 述べよう.

\section{アルパームについて}

$\mathrm{Fe}-\mathrm{Al}$ 系合金の弓ち $\mathrm{A} 110$ 18\% を含む合金は焼 鈍

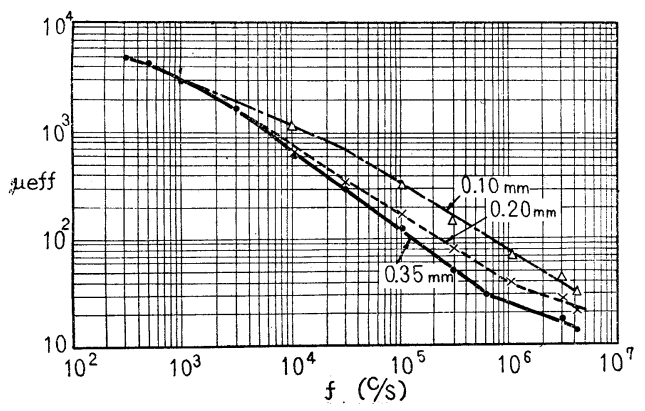

第 2 図種々の厚さの Alperm 板の $\mu_{\mathrm{eff}}$ 周波数特性

\section{第 3 図}

Alfenol 打よ び Permalloy 製 ヘッドの損失

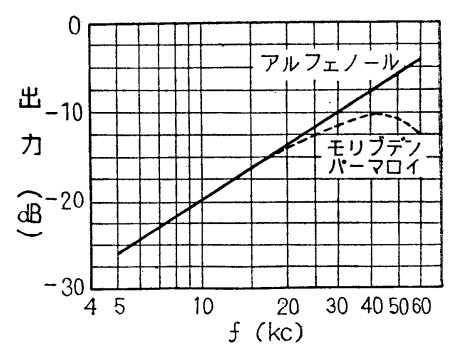

状態では $\mathrm{Fe}_{3} \mathrm{Al}$ 規則格子を形成する.しかしこれを $500^{\circ}$ 〜 700 から急冷して規則格子の生成を抑制すると $\mu$ が大 きくまた 0 も大きくなることは 1939 年增本と斉藤 ${ }^{(3)}$ とによって見出された、しかしたまたま戦時に際会した のと, 当時のわが国工業界の水準のためから, 比較的硬 いこの合金は遂に実用化されないままであった。戦後,

米, 独に招いて注目をひき, 加工法が研究され, それぞ れ Alfenol 16 扔よび Vacodur 16 の名で市販されるに 到った.このことによってわが国でも再び注目され，数 社ですでに試作段階を終っている. 現在 Alperm と呼ば れるものは上記組成範囲の中でも最も $\rho$ が大きく, 機械 的硬さの大きい $16 \% \mathrm{~A} 1$ 合金である. 第 2 図には市販ア ルパームの高周波特性 ${ }^{(4)}$ が示してある.この合金の高 $\mu$, 高 $\rho$, 高硬度に着目して始めて録音用へッドに利用した のは Fishe11(5) 拈よび Lufcy ら(2)であった。第3図は 同様浩った Alfenol 16 拉よび Mo-permalloy 製ヘッ ドの特性を比較したもので, $10 \mathrm{kc}$ までは両へッドとも に特性は㴗とんど変わらないが，10 kc を超光ると Permalloy ヘッドでは損失が大となるのに反し, Alfenol 製へッドは $60 \mathrm{kc}$ までほとんど理想的特性を示してい る. 国産 Alperm について行なわれた試験結果もほと えどこれと差がない(6).

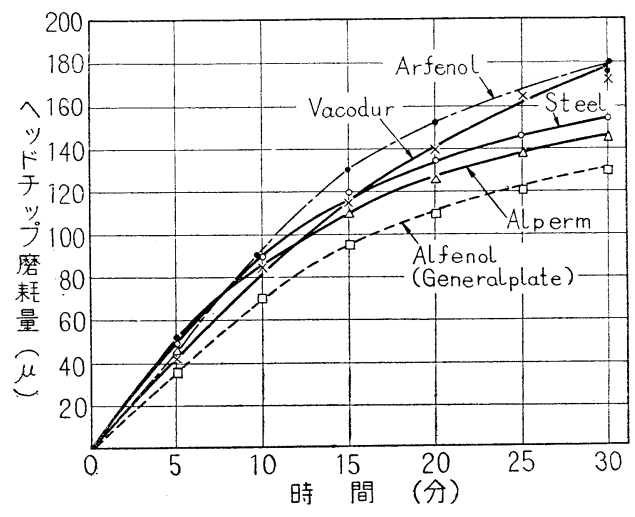

第 4 図 各種 Alperm とバネ鋼のヘッドチップ 磨耗量の比較 


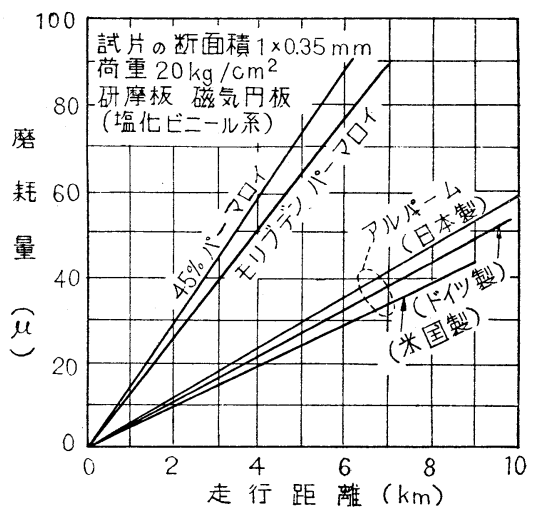

第 5 図Alperm と Permalloy の磨耗量の比較

このような Permally 系材料と Alperm 系材料での ヘッドの性能の差はもちろん両材料の特性の差によるも のである. 第 1 表はその特性を比較したものであるが， 磁性の点では Permalloy の方が遙かに優れているのに Alperm 系材料のヘッドが良好な特性を示すのは，第 1 にその $\rho$ が大きいこと，第 2 に Lufcy ら(2) も指摘して いるょうに Alperm 系材料は機械的に硬いので間隔部 周辺の残留ひずみが小さく， $\mu_{\text {eff }}$ の低下が少ないこと, また打抜き周辺部のダレが少ないことが原因として考光 られよう。

豆らに Alperm の特徴の一つは第 4 図 ${ }^{(7)}$ に例示するよ 亏にロックウエル硬さ Rc60 のバネ鋼とほぼ同程度の耐 磨耗性を有することである．また第 5 図 ${ }^{(8)}$ は各種 Permalloy と比較したもので，ヘッド用材料として Alperm が最適とされる決定的要因の一つである.

さて第 2 図で見たよ5に Alperm の $\mu_{\text {eff }}$ は $0.1 \mathrm{~mm}$ の厚さの板でも $4 \mathrm{Mc}$ では数十程度にすぎない，そのた め，いますこし $\mu_{\text {eff }}$ の大きな材料が要求されているの で, 筆者は数年前から日本楽器の協力を得てさらに薄い 材料の試作を行なっている.

なお Alperm について約 2 年連続して測定した結果， その磁性には時効現象はまったく認められなかった ${ }^{(9)}$.

\section{アルパーム $20 \mu$ 板について}

上述のようにさらに薄い材料が要求されるのに Alpe$\mathrm{rm}$ の厚さ $0.1 \mathrm{~mm}$ の板の製造は現状では決して容易な ことではない.よって筆者は菊田(10) と共にごく薄い純 $\mathrm{Fe}$ あるいは低 $\mathrm{Al}$ 含有量の $\mathrm{Fe}-\mathrm{A} 1$ 板に $\mathrm{Al}$ を浸透させ て約 $20 \mu$ の厚さの Alpermを試作した. このように薄 い板では粒子も小さくなり，必然的に $\mu$ は低下するが $W_{e}$ の低下がこれを補うであろうし，また粒子が小さい

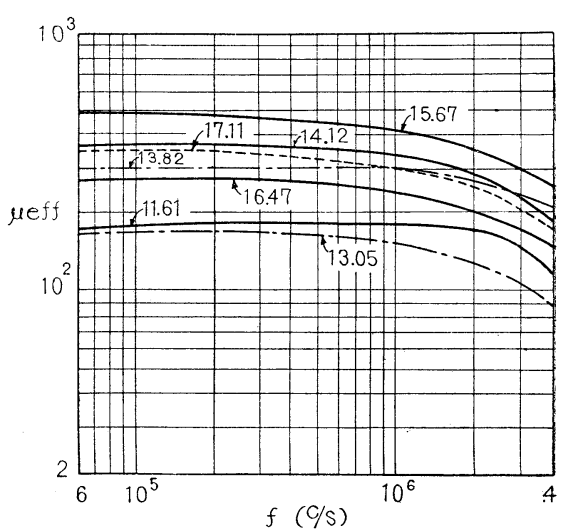

第 6 図 $20 \mu$ 厚さの $\mathrm{Al}-\mathrm{Fe}$ 合金の $\mu_{\mathrm{eff}}$ 周波数特性

と打抜き性（ダレ）などかえっよくなるものと予想さ た、試作の結果はほぼ予想ど扣りであった，第 6 図はこ の方法で造った種々の Al 含有量の薄板の $\mu_{\mathrm{eff}}$ 特性曲 線(11)であり，この図から 13.5〜16.5\% Al の組成範囲 の薄板は $4 \mathrm{Mc}$ でも 150 以上の $\mu_{\mathrm{eff}}$ を有し, 材料と しては十分の特性のものであることがわかる. しかしこ れらの材料について各所で実際にヘッドとして御試験願 った結果は，先に述べたへッド当面の問題がそのままあ てはまる結果となった。第 7 図は NHK でへッドとして 試験された結果を同所で開発された改良型へッドと比較 したものである.このように薄板材料製へッドがかえっ て性能が悪い最大の原因は材料がごく薄いため残留ひず みの影響であろ5. 写真 1 はこの素材について松下中研 で撮影されたX線写真であり，写真 2 はこの薄板を 11 枚張り合わせ，レジンで接着しプレスしたもので，すで に著しいひずみが発生していることがわかる.これを除 くことが当面の課題であるが，レジンの溶融点が低いの でひずみ処理は低温で行なわねばならぬ.この場合には 先に述べた $\mathrm{Fe}_{3} \mathrm{Al}$ 規則格子の生成とそれに伴う $\mu$ 少よ び $\rho$ の低下が問題となる. 写真 3 は同じ素材を焼鈍後炉

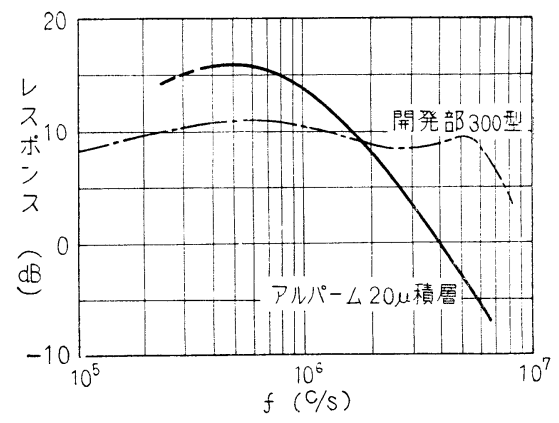

第 7 図 NHK 300 型捻よび積層型へッドの周波数特性 


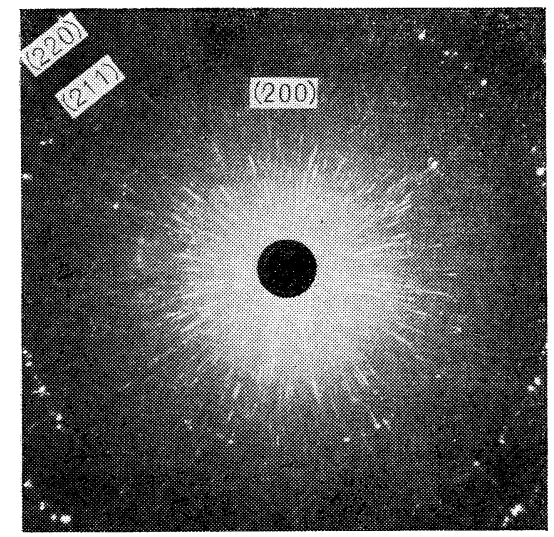

写真 $120 \mu$ 厚さの Alperm 素 材のX線写真

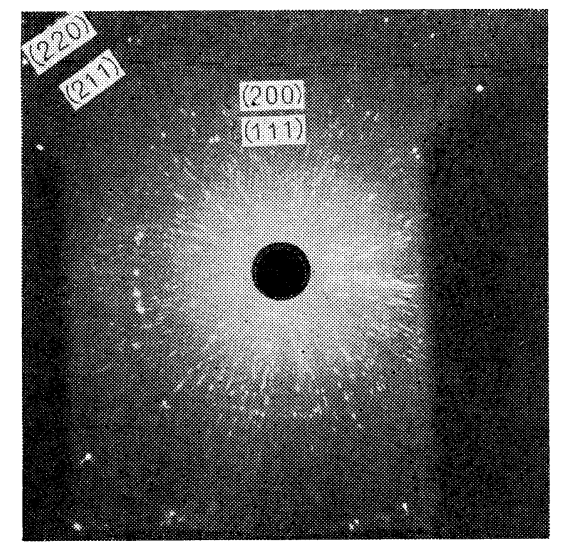

写真 3 写真 1 の素材を焼鈍後 $50 \%$ 時の速さで 冷却したもの

冷したもので，この程度の処理でも判然と規則格子線 [III]が現われ，低温焼鈍に伴万困難性を示している.

\section{今 後の 問 題}

以上簡単にヘッド用材料の当面する問題を述べたが，

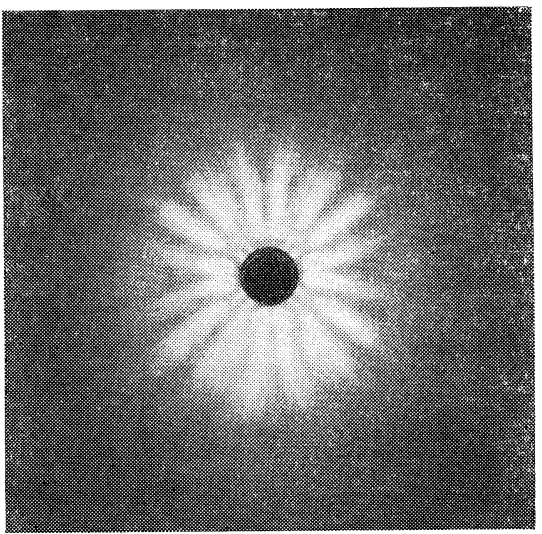

写真 2 写真 1 の素材を 11 枚はり あわせプレスしたるの

板材に関しては現在の製造 方法では薄くすることも困 難であり，皇た多少薄くし ても多くは望めない。した がって薄板積層ヘッドの改 良をいかにするかである。

そのためには

（1）積層貼り合わせ用 接着材としてレジン以 外の絶縁性の強い, 乙 かも型抜きあるいは加 工後再び熱処理の可能 なものの研究.

(2) 機械的な硬さが Alperm よりもさらに大きく, $\mu, \rho$ の大きな材料の 研究.

が今日の主目標であらねばならない、筆者もこの両面に わたり研究を続けているが，近く報告できるものと信じ ている.

最後に，貴重な資料の引用を快く許可された NHK 技 研, 松下中研の各位に心から报礼申し上げて筆を拉く.

(昭和 35 年 12 月 9 日受付)

$$
\text { [参考文 献] }
$$

（1）寺山・電子科学， 9 (1959)，30，植渡：電子科学。 9 (1959) 33

(2) C.W. Lufcy, W.T. Heath : Electronics, (1955) June, 137

（3）增本, 斎藤: Sci. Rep. RITU, A-3(1951), 523 : A-4 (1952) $321 ; 338$

（4）日本楽器ヤマ八合金カタログ火よる.

(5) R.E.Fishell : Communication and Electronics. 1955. 05. P. 190.

（6）例えば東通工（現ソニー）で行なわれた試験報告.

(7) 松下電器中央研究所の測定による.

（8）松岡：昭和 35 年度電気通信学会全国大会汇拈计る掯演。

（9）斎藤：近く日本金属学会誌溌登の予定.

（10）斎藤, 菊田：日本金属学会昭和 35 年度秋期（第 47 回）大会飞拉 ける牶演.

(11） NHK技術研究所の測定による。

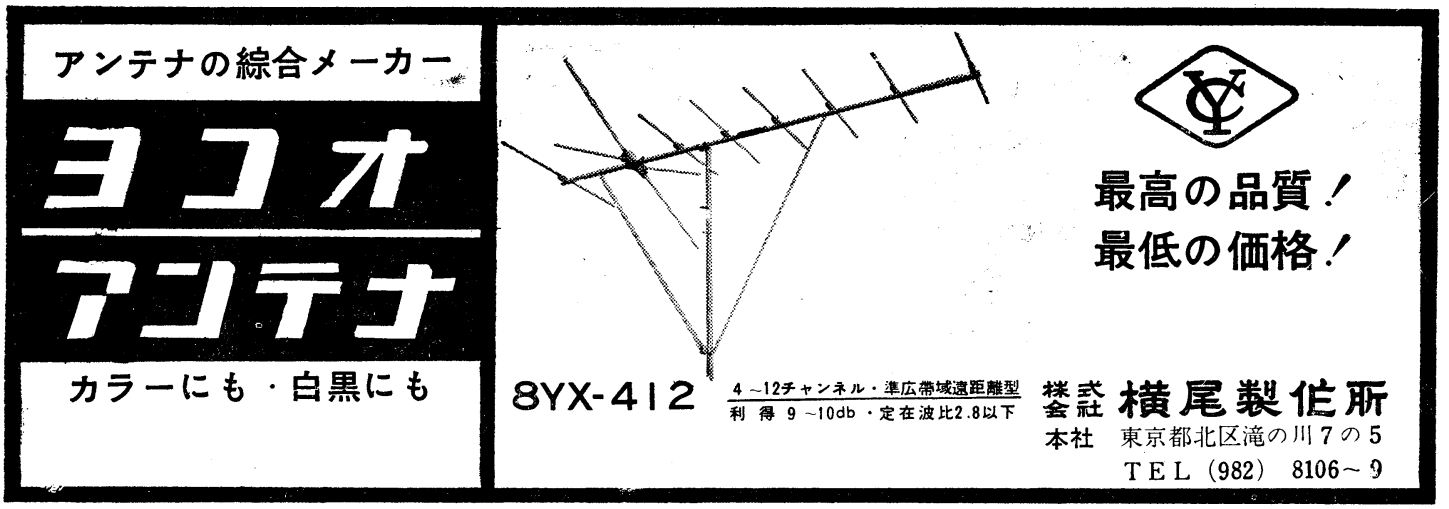

